\title{
5. 計画の現状と課題
}

\section{The Actual Situation and Problem for the Plan}

高 橋 昇*

Noboru Takahashi

\section{1 雪国における学校建築計画の現状}

近年，建設された学校建築は教育改革に伴い，多 様な学習形態への対応，児童・生徒のためのゆとり と潤いのある「生活の場」つくり，さらに情報化・ 国際化への配虑, 生涯学習施設としての学校つくり などを目指したものとなっている。

雪国の学校建築でも, 同樣の傾向であり, 雪国で はこれらの課題に加えて，冬期における積雪や寒冷 への対策が重要であることは言うまであない。また 雪国の学校は，一般的に小規模校である場合が多く 地域との連携のあり方む重要な課題となっている。

そこで本項では，雪国における学校建築の計画の 現状と課題を把握するため, いくつかの事例から， 雪国の条件を考虑した計画上の項目を抽出し，下記 に示す ${ }^{1 \sim 4)}$ 。

\section{a. 配置計画上の配慮}

1) アプローチ（動線）の確保

(除雪と雪処理スペースのゆとり)

2）季節風を遮るブロックプラン

（校舎，体育館などを北西方向に配置）

3）屋根の形状と建物のレイアウト

（落雪と落雪した雪処理を考えた配置）

b. 平面計画上の配慮

1）アプローチから算降口・出入口へのアクセス (ピロティとする)

2）冬期の生活空間の拡がりを確保

（ピロティとし，雪囲いをする）

3）乾燥室（スキー）や風除室の設置

4）ランニングコースや様々な活動への対応 （ピロティとする）

5）季節風を考虑した出入口の位置選定 （必要に応じて大きな庇を掛ける）

c. 学校之地域連携上の配慮

1）施設の複合化（幼・小・中学校，その他）
2）地域の中心施設としての位置つけ

3 ）生涯学習施設として活用（学校施設の開放）

d. その他の配慮

1）地場産の木材利用（内外装材，構造材として）

2）地場産の瓦利用（地域の活性化を考虑）

3）設備等の凍結防止

4）皘雪量を考虑して高床式

5) バルコニー上の媣い軒先

6）暖炉などで温もりのあるインテリアつくり

7）環境負荷への配虑（パッシブデザイン）

8）周辺環境との調和，景観への配虑

（風景之の調和, 傾斜屋根など）

このように，雪国における学校建築の現状は，計 画上いかに冬期間の対策が重要であるかが解る。

一方，た之元雪国でむ冬期間以外の生活か，6 6 ケ 月前後むあり，また日本列島は大陸との地勢の関係 で高温多湿の条件が伴うことなど忘れてはならない。

このような自然環境条件を考㦄した場合, 熱環境 としては「閉鎖的」で，通風や生活空間の拡がりを 求める点では「開放的」という要件の解決が, 雪国 における学校建筑の重要な課題となる

\section{2 伝統技術・空間との類似点}

前節で抽出した，雪国における学校建筑計画上の 項目の中で, 例えば, ピロティ, 風除室, 畭燥室な どは, 明らかに雪国における伝統技術・空間との類 似性が窥われる。これらは現代的に翻訳されたもの であり，機能性において同じであることが解る。

そこで本節では，現代の事例と伝統技術・空間と の類似性について考察する ${ }^{6)}$ 。

a . 土縁とピロティ

土縁は, ドエン, ツチエン，またはロウジと地方 によって呼び方が異なる。しかし，機能性では殆ど 同じである。土縁は，鳥根から秋田にかけての豪雪 地带に分布しており，積雪時の生活空間と動線の確

* 仙台デザイン専門学校 建築デザイン科 科長 
保を目的とするもので，また夏には，建物と庭との 間を繋ぐ䋧衝空間となる。

つまり，土縁は，冬期には閉鎖的，夏期には開放 的と目的に添って変化し，生活に潤いを与える装置 と言える。土縁の構造は，建物側の半分を縁とし， 庭側の残り半分を土間としたすので，これは先に指 摘したように，ピロティとして生活空間の搪がりや 動線の確保を目的した考えと同じである。このよう に，現代建築に奥床しさを与えるため，伝統技術・ 空間に学ぶことは有意義な方法のひとつである。

また，街路との関係で同様の機能性を発揮するむ のとして，小店や倠木がある。これは現代でのアー ケードそのものであり，雪国ならではの発想と言える。 これも積雪時の動線確保が目的であるか，地方によっ ては，収納スペースとして活用している例もある。

土縁・小店・雁木は，季節に対応し雪囲いを取り つけたり，外したりすることによって，空間を可変 させる伝統技術・空間であり，多様な生活空間を演 出する装置となる。

\section{b，アマヤと風除室}

アマヤは，雪アマヤ，冬アマヤ，雪棚などとも言 われるもので，冬を迎えると柱を建て梁を掛け，外 側には茅束を建て込み，屋根面には茅筫をのせるも のである。このアマヤは，積雪時の道路から建物ま での動線を確保し, 冬の生活へ備えるものであるが, 同時に季節風を遮る風除室の役割も果たす。

そして, アプローチが長い場合は長いトンネル状 になると言われるが，いずれの場合でも動線の確保 や風除けはもとより, 除雪道具などの置き場として む利用するむのらしい。このような機能を発揮する アマヤは，のちに中門造りに変化したとされる説を， 成程と納得させるに充分と言えるものである。

\section{c.土間亡乾燥室}

土間は，出入り，作業場，一時的な収納スペース 雨具掛け，防寒着の雪払いなど，多様な生活行為を 許容する空間である。

その意味において, 乾燥室を設ける場合は, スキー や防寒着の乾燥にとどまらず，除雪道具など収納ス ペースとして利用することなども考虑されてよい。

\section{d. 雪囲い}

雪囲いは，積雪や吹雪から開口部あるいは壁を守 るために取り付けるものである。雪囲いには，お之
し板（雪板，囲板ともいう）とする地域，大和障子 とする地域，あるいは茅筫や茅束を建て込む地域な どがあり様々である。

雪囲いの取り付け，取り外しは，建物の衣替えと 言えるもので，雪国の風物誌である。そこで，雪囲 いの取り付け，取り外しを児童・生徒と地域住民が ともに行えば，地域性を学ぶ交流の場となる。

\section{3 雪国の学校づくりにおける課題}

以上，雪国における学校建築の事例加，雪国の 条件を考虑した計画上の項目を抽出し，伝統技術・ 空間との類似性について言及してきた。

この節では，本項のまとめとして，雪国における 学校建築の計画上の課題を列挙すると,

(1)地域性を考虑した学校つくらのコンセプトを明確 にすること

(2)伝統技術・空間に学び, 豊かな空間つくりに活か すこと

(3)地域との連携を考えたコミュニティスクールつくく りを目指すこと

(4)積雪寒冷は雪国の個性のひとつであり，他の地域 色と同様に尊重し充分な対策を行うこと

(5)環境に配虑した計画を行うこと

(6)余裕教室や既存 RC 造校舎の再利用にあたっては 耐震診断を行い耐震補強をすること

(7)防災拠点としての学校つくりという観点から皘雪 時の地震などの災害発生の可能性についても充分 配慮した計画を行うこと などに要約できる。

さらに，時代性を考えるとユニバーサルデザイン の視点による施設つくりが求められるなど，障害者 や高秢者への配虑はむとより，すへてての人々が利用 し易い学校づくりも今日的課題である。

\section{【参考文献】}

1）長倉康彦編著 : 学校建築の変革一開かれた学校の設 計・計画, p9, pp88-89, pp95-102, 彰国社, 1993

2）建築思潮研究所編：「建築設計資料」16, 学校, pp133-138，建築資料研究社，1987

3）建築思潮研究所編：「建築設計資料」40，木造の教 有施設, pp117-123，建築資料研究社，1993

4）建築思潮研究所編：「建築設計資料」62, 学校 2 , pp16-17，建築資料研究社， 1998

5）佐藤勝泰：家のつくりようは北をむねとすべし， $\mathrm{p} 72, \mathrm{pp} 85-86$, トーソー出版, $\mathrm{H} 2$

6) 安藤邦廣, 乾 尚彦, 山下浩一：住まいの伝統技術, $\mathrm{pp} 38-65$ ，建築資料研究社， 1995 